\title{
New Elements on the Hairech Metamorphic Massif Structure (Northwest Tunisia). Geoelectrical Prospecting Contribution
}

\author{
Rihab Guellala (Corresponding author) \\ Laboratoire de Géoressources, Centre de Recherches et des Technologies des Eaux \\ Technopole de Borj Cedria, 8020 Soliman, Tunisia \\ E-mail: gallalarabie@yahoo.fr \\ Mohamed Hédi Inoubli \\ University of Sciences of Tunis, Tunis El Manar, Universities Campus 2092, Tunis, Tunisia
}

Faouzi Amri

Ministry for Agriculture and the Water Resources, Alain Savary Street, 1002, Tunis, Tunisia

Received: June 17, $2010 \quad$ Accepted: June 29, $2010 \quad$ doi:10.5539/jgg.v3n1p160

\begin{abstract}
A geoelectrical survey was carried out in order to better understand the subsurface geology of the metamorphic massif of Hairech (Tunisia). Over 50 Schlumberger electrical soundings were performed using a maximum electrode spacing of $3000 \mathrm{~m}$. The carried out qualitative interpretation of resistivity distributions for various depths is based on apparent resistivity maps that were constructed for different AB spacings.

Quantitatively, the measured resistivity values were one-dimensionally interpreted. The already drilled boreholes and the position of some electrical soundings on geological outcrops have been helpful for electrical data calibration.

The results of the vertical electrical soundings reveal that the metamorphic Hairech massif, correspond to a folded structure which is affected by deep trending east-west to northeast-southwest faults.
\end{abstract}

Keywords: Tunisia, Metamorphic, Hairech, Geoelectrical survey, Folded, Faults

\section{Introduction}

Africa is characterized by many metamorphic zones. Several zones were subject of various studies (Ring et al., 1997; Aghzer \& Arenas, 1998; Agbossoumonde et al., 2001; Caby et al., 2001; Diener et al., 2005).

In northern Tunisia, the Hairech-Ichkeul domain (Figure 1a) exhibits the oldest metamorphic formations dated Permo-Triassic to Triassic and Jurassic (Alouani et al., 1991). Cropping out in the front of the overthrusting domain (Rouvier, 1773; Martinez \& Truillet, 1987) along a northeast-southwest trending axis, this area behaves as a paleoridge, qualified as Hairch-Ichkeul ridge. This domain which emerged at the Lower Eocene period (Glaçon \& Rouvier, 1972) constitutes the continuation of the Eastern constantinois mole-Algeria (Bolze, 1950; Burollet, 1973; Vila, 1980).

Few authors have investigated the Hairech and Ichkeul metamorphic massifs. Discussions dealt with their age (Bolze, 1954; Durand Delga, 1955; Gottis \& Sainfeld, 1955; Burollet, 1973; Rouvier, 1977), genesis and structural position (Alouani \& Tlig, 1988; Alouani et al. 1991; 1997).

Most of the previous works were restricted to surface and little is known about their subsurface geology.

This study, which is based on the electrical resistivity method (Keller \& Frischknecht, 1982), aims to infer a more accurate picture of the inland area of the Hairech massif (Figure 1). The used procedure includes the use of conventional vertical electrical sounding through the identification of resistivity layering along specific cross-sections. 
The electrical resistivity method provides wide applications in structural (Caglari \& Duvarci, 2001; Epov et al., 2007), sedimentary (Bersezio et al., 2007), hydrogeological (Zouhri et al., 2004; Asfahani, 2006; Guellala et al., 2009) and geothermal (Majumdar et al., 2000) studies.

\section{Geology}

Located in the northwestern part of the Mejerda molassic basin (Burollet \& Rouvier, 1971; Rouvier, 1977), the Hairech massif (Figure1b) presents two sedimentary megasequences expressing distinct metamorphic histories (Alouani \& Tlig, 1988).

The Hairech series made of sandstones and schists intercalated with metric dolomite underwent anchizonal metamorphism. These lithofacies, thicker than $900 \mathrm{~m}$ (borehole observation, Figure 2), are dated Triassic (Bolze, 1954; Rouvier, 1977; Perthuisot, 1978) or even Permian-Triassic (Burollet, 1973; Alouani et al., 1991).

The surrounding Hairech series, made of marbles and dolomites, are considered as a Liassic deposits (Durand Delga, 1955; Gottis \& Sainfeld., 1955; Rouvier, 1977; Alouani, 1991). This interval is characterized by hydrothermal metamorphism. These series which are intensively fissured and karstified (Alouani \& Tlig. 1988; Alouani et al., 1997) constitute the regional aquifer (Manaa, 1986).

The Mejerda basin is filled with sedimentary deposits ranging from Mio-Pliocene to Quaternary in age. The Quaternary sediments are made of clays, gravels and sands (Gottis \& Sainfeld, 1955), whereas the Mio-Pliocene sediments consist on conglomerates, sandstones, clays and marls (Gottis \& Sainfeld, 1955; Biely, 1972). Borehole g, drilled by Water Resources Directorate of Tunisia in the south of Hairech massif (Figure 2), reveals a Mio-Plio-Quaternary thickness exceeding $170 \mathrm{~m}$.

From the tectonic point of view, Fej el Temer fault system (Figure 1b), separating Hairech series and Chouichia Cretaceous and Eocene formations (Gottis \& Sainfeld, 1955; Rouvier, 1977), express the dominant tectonic feature in the region. Seismological studies (Hfaiedh et al., 1985; Ben Ayed, 1986; Gueddiche et al., 1992) show the continuous activity of this northeast-southwest trending system.

\section{Data and methodology}

Vertical Electrical Sounding (VES) data acquisition was performed at 52 locations (Figure 2). The Schlumberger configuration was performed, considering a maximum electrode spacing of $3000 \mathrm{~m}$. An electrical field is imposed on the inland area by a pair of electrodes (A and B) at varying spacing, expanding symmetrically from a central point, while measuring the surface expression of the resulting potential field with an additional pair of electrodes ( $\mathrm{M}$ and $\mathrm{N})$ at appropriate much smaller spacing. Apparent resistivity " $\mathrm{pa"} \mathrm{is} \mathrm{subsequently} \mathrm{computed}$ according to the following equation:

$$
\mathrm{ra}=\frac{2 \pi}{(1 / \mathrm{AM})-(1 / B M)-(1 / A N)+(1 / B N)} \frac{\Delta \mathrm{V}}{\mathrm{I}}
$$

(Dobrin, 1976)

Where, $\mathrm{I}$ is the current introduced into the earth by $\mathrm{A}$ and $\mathrm{B}$ electrodes, and $\Delta \mathrm{V}$ is the potential difference between $\mathrm{M}$ and $\mathrm{N}$ electrodes.

Apparent resistivity data, obtained at each vertical electrical sounding for different $\mathrm{AB}$ spacings, are arranged and contoured in the form of resistivity maps that express a qualitative representation of resistivity distributions for various depths.

For quantitative interpretation, the resistivity data were one-dimensionally evaluated.

The determination of initial thicknesses and resistivities are obtained by manual matching the VES field curves to the theoretical master curves and auxiliary point charts. These parameters are subsequently refined using an inverse technique implemented in WINSEV program (Jenny \& Borreguero, 1993). The result is achieved when a good fit between the field data and the theoretically computed curve is obtained.

Interpretation problems, such as equivalence or suppression, show that the same electrical sounding curve $\rho \mathrm{a}=\mathrm{f}$ $(\mathrm{AB} / 2)$ may result into different geoelectrical models. Geological data were compulsory in order to constrain the results and to solve the observed ambiguities, so that interpretation ends up to a realistic geological modeling.

The already available boreholes (Figure 2) allowed the calibration of the proximal VES. This information was used to lead the inversion results and to help producing good and accurate pictures of the subsurface geology.

\section{Interpretations and results}

\subsection{Resistivity maps}

The apparent resistivity values in Figure $3 \mathrm{a}(\mathrm{AB}=200 \mathrm{~m})$ and Figure $3 \mathrm{~b}(\mathrm{AB}=1000 \mathrm{~m})$ are respectively influenced by shallow and deep inhomogeneties. 
Figure 3a indicates that jebel Hairech and Kef El Agueb (Liassic in age) series are characterized by high resistivity values $(>150 \mathrm{Ohm} . \mathrm{m})$, whereas the Mejerda molassic basin (Mio-Plio-Quaternary sediments), corresponds to a conductive region.

Figure $3 \mathrm{~b}$ reveals low resistivity zone $(<50 \mathrm{Ohm} . \mathrm{m})$ in the Kef El Agueb massif. The absence of high resistivity values suggests that the metamorphic layers made of dolomites and marbles do not extend to deeper levels. Whereas high resistivity contours $(100-150 \mathrm{Ohm} . \mathrm{m})$ still persist near the jebel Hairech. This response can be explained by the important thickness of the Hairech series (sandstones, schists and dolomites), which exceed $900 \mathrm{~m}$.

Both Figure 3a and Figure 3b show east-west and northeast-southwest trending of the apparent resistivity contours.

\subsection{Vertical electrical soundings calibration}

The electrical identification of the Hairech series was possible thanks to VES 32. Substrata are homogeneous; therefore, apparent resistivity is good approximation of the true resistivity. A value of $155 \mathrm{Ohm} . \mathrm{m}$ is typical for the Hairech series (Figure 4).

Compared to the geological data provided by the boreholes (a, b, c and d), the VES (3,11, 15 and 21) show a resistivity ranging from 100 to $200 \mathrm{Ohm} . \mathrm{m}$ for Liassic dolomites and marbles (Figure 5). Resistivity variations can be ascribed to the pore fluid chemistry. Fresh waters tend to be resistive while saline brines are very conductive (Telford et al., 1976).

VES48 calibrated with lithological column of borehole $\mathbf{g}$ allows the determination of the specific resistivity of the Mio-Plio-Quaternary series (Figure 6). The obtained values range in a low to moderate interval: 5-32 Ohm.m.

The calibration results, which constitute a guide for the vertical electrical soundings interpretation, are helpful for the construction of the geoelectrical cross-sections.

\subsection{Geoelectrical cross-sections}

Six geoelectrical cross-sections are established along northeast-southwest and northwest-southeast directions. The most representative cross-section is exposed in Figure7. Through its vertical and horizontal resistivity variations, this section clearly reflects an irregular subsurface structure.

The resistive 140m thick zone (130 Ohm. m) beneath VES33, rooted near the kef El Agueb massif, may express the continuity of the Liassic metamorphic formations. This is underlain by a conductive $13 \mathrm{Ohm} . \mathrm{m}$ layer which can be correlated with the Triassic rocks made of clays, dolomites and gypsum. Nearby, VES32 characterizes the resistivity Hairech series which read $155 \mathrm{Ohm} . \mathrm{m}$.

According to the inferred geoelectric models, a Permo-Triassic age would be more logical for the highly resistive Hairech series. This result corroborates the works made by Burollet, 1973 and Alouani et al., 1991.

Relying on the observed sudden resistivity change between neighbor locations VES 33 and VES 32 and the tectonic contact between the Liassic outcrops (Chemtou, Sidi Assem, Koudiat Nouamia and Sidi Abdallah) and Hairech jebel revealed by the geological map (Figure1a), a fault Fa (Figure7) that separates the kef El Agueb Liassic layers from the Hairech series is strongly suspected.

The observed 152 and 148 Ohm.m resistivity values at VES31 and VES30 are close to the characteristic Hairech series resistivity. This allows the extension of the metamorphic formations towards the north, beyond jebel Hairech.

The low resistivity responses (2-33 Ohm.m), expressed beneath VES29, VES30, VES31, VES33, VES26, VES27 and VES28, are diagnostic of the Mio-Plio-Quaternary deposits. These layers are much more developed towards the Medjerda molassic basin.

The thickness decrease of the conductive zones located at VES33, VES31 and VES30 translates the thinning of the Mio-Plio-Quaternary cover over the metamorphic formations. It is interesting to note that beneath VES33, this cover points up a small depression which is individualized between Hairech and Kef El Agueb raised structures. This suggests that the metamorphic formations are folded into anticline and syncline shape structures.

It is clearly visible that the northern and southern parts of cross-section 4 (Figure7) reflect lateral resistivity discontinuities. The high resistivity layers consisting of the Hairech and the Liassic series disappear abruptly at VES 26 and VES 29 locations which resistivity (lower than $35 \mathrm{Ohm} . \mathrm{m}$ ) fits the electric response of the 
Mio-Plio-Quaternary deposits. The geoelectric discontinuities match with the extension limit of the Hairech metamorphic massif (Liassic and Hairech series); it may indicate also $\mathrm{Fb}$ and $\mathrm{Fc}$ faults (Figure7).

\subsection{Subsurface geological maps}

As a synthesis of the vertical electrical soundings' results, subsurface geological maps are constructed (Figure 8). The maps, drawn for 50, 150 and $250 \mathrm{~m}$ depth levels, reflect the lithological variations and characterize the structuring of the studied area.

The 50m depth map level (Figure 8a) shows a succession of northeast-southwest folds: Kef El Agueb massif and the eastern part of the jebel Hairech correspond to anticlinal structures separated by a small syncline, filled with Mio-Plio-Quaternary sediments. Similar structural features were described in the Medjerda molassic border and attributed to the Neogene compressive phases (Rouvier, 1977; Ben Ayed, 1986; Ould Bagga, 2003). This suggests that Hairech metamorphic massif was folded during these phases.

The Neogene compressive phases are described in the Atlas (Zouari, 1995; Amrhar, 2002) and Iberic belts (Lepvrier et al., 1984). They are linked to Africa and Europe convergence (Ricou, 1994).

$150 \mathrm{~m}$ deeper (Figure $8 \mathrm{~b}$ ) a quite different pattern is outlined. The Mio-Plio-Quaternary cover response is not observed. Kef El Agueb Liassic layers and Hairech series are in contact through a northeast-southwest directed fault. The limits between Hairech metamorphic massif and Medjerda basin are drawn by east-west to northeast-southwest directed faults. Following these directions, geometrical contours of jebel Hairech and Kef El Agueb massif reflect the signature of fault activity.

The ENE-WSW trending faults are the predominating features is the Mediterranean region where the ongoing convergence between Africa and Europe is accommodated by subduction (Morel et al., 1996; Domzig et al., 2006).

Figure $8 \mathrm{c}$, representing the deeper $250 \mathrm{~m}$ map, expresses a quite similar structural geometry to that one exposed in Figure $8 \mathrm{~b}$, thereby indicating a deep faulting. However, a vertical lithological change is noticed at Kef El Agueb massif. So, Liassic layers disappear in favor of Triassic deposits.

The east-west to northeast-southwest fault activities and the Neogene folding constitute the two mechanisms contributing to the structuration of the Hairech metamorphic massif. These mechanisms are well expressed by the elaborated subsurface geological maps.

\section{Conclusion}

In this paper, we have presented new results based upon resistivity mapping and one dimensional geoelectrical modeling of the inland area of the Hairech metamorphic massif.

The geoelectrical data have shown the following:

- Hairech series, consisting of sandstones, schists and clays, are characterized by a resistivity as high as 155 Ohm.m. They extend towards the north, beyond jebel Hairech location. Their thickness exceeds $900 \mathrm{~m}$.

- The resistivity range 100-200 Ohm.m is typical of the Liassic dolomites and marbles. These metamorphic formations, which average thickness is $160 \mathrm{~m}$, are underlain by the Triassic conductive layers (10-18 Ohm.m) consisting of clays, dolomites and gypsum.

- The Hairech metamorphic massif is a folded northeast-southwest directed structure. Neogene compressive phases may be responsible of this folding. The small syncline, separating Kef El Agueb and Hairech jebel anticlines, constitutes the receptacle of a thin Mio-Plio-Quaternary sedimentation.

- The structural pattern is affected by deep faults expressing the abrupt lateral resistivity variations. A northeast-southwest fault insures the contact between Kef El Agueb Liassic formations and Hairech series. Additionally, the conductive Mio-Plio-Quaternary deposits $(2-35 \mathrm{Ohm} . \mathrm{m})$ filling the Medjerda basin, are separated from the metamorphic formations by east-west to northeast-southwest trending faults.

- The geometry of Hairech metamorphic massif is the result of the east-west to northeast-southwest faults activity associated to the Neogene folding.

\section{References}

Agbossoumonde, Y., Menot, R. P., \& Guillot, S. (2001). Metamorphic evolution of Neoproterozoic eclogites from south Togo (West Africa). Journal of African Earth Sciences, 33, 227-244. doi:10.1016/S0899-5362(01)80061-0, http://dx.doi.org/10.1016/S0899-5362(01)80061-0 
Aghzer, A. M. \& Arenas, R. (1998). Evolution métamorphique des métapélites du Massif hercynien des Rehamna (Maroc): implications tectonothermales. Journal of African Earth Sciences, 27, 87-106. doi:10.1016/S0899-5362(98)00048-7, http://dx.doi.org/10.1016/S0899-5362(98)00048-7

Alouani, R. \& Tlig, S. (1988). Bimodal metamorphism and successive dolomitizations of two superposed megasequencs at the jebel Hairech (northwestern Tunisia). C. R. Géoscience, 306, 1373-1378.

Alouani, R. (1991). Le Jurassique du Nord de la Tunisie. Marqueurs géodynamiques d'une marge transformant: Turbidites, Radiolarites, Plissement et Métamorphism, PhD thesis, University Tunis II. 202 p.

Alouani, R., Adil, S., \& Mouguina M. (1991). Allochtonous metamorphic units of the axis of Jebels Hairech and Ichkeul: structural position and geodynamic significance in northern Tunisia. $C$. $R$. Géosciene, 313, 421-426.

Alouani, R., El Khachani, H. \& Melki, F. (1997). Découverte du Jurassique supérieur dans des écailles carbonatées liasiques de Jebel Hairech-Kef el Agueb (Tunisie septentrionale): Notes du Service Géologique de Tunisie, 63, 5-14.

Amrhar, M. (2002). Paléocontraintes et déformations syn- et post-collision Afrique-Europe identifiées dans la couverture mésozoïque et cénozoïque du Haut Atlas occidental (Maroc). C. R. Geoscience, 334, $279-285$. doi:10.1016/S1631-0713(02)01730-3, http://dx.doi.org/10.1016/S1631-0713(02)01730-3

Asfahani, J. (2006). Geoelectrical investigation for characterizing the hydrogeological conditions in semi-arid region in Khanasser valley, Syria. Journal of Arid Environments, 68, 31-52. doi:10.1016/j.jaridenv.2006.03.028, http://dx.doi.org/10.1016/j.jaridenv.2006.03.028

Ben Ayed, N. (1986). Evolution tectonique de l'avant pays de la chaîne alpine de la Tunisie du début du mésozoïque à l'actuel, $\mathrm{Ph} \mathrm{D}$ thesis, University Paris VI.

Bersezio, R., Giudici, M. \& Mele, M. (2007). Combining sedimentological and geophysical data for high-resolution 3-D mapping of fluvial architectural elements in the Quaternary Po plain (Italy). Sedimentary Geology, 202, 230 -248. doi:10.1016/j.sedgeo.2007.05.002, http://dx.doi.org/10.1016/j.sedgeo.2007.05.002

Biely, A. (1972). Le Néogène en Tunisie septentrionale. Report of geological office, Tunisia

Bolze, J. (1950). Diapirs triasiques et phases orogéniques dans les monts de Téboursouk (Tunisie septentrionale). C. R. Géoscience, 231, 480-482.

Bolze, J. (1954). Age des séries schisteuses et dolomitiques de l'Ichkeul et de l'Hairech.(Tunisie septentrionale). C. R. Géoscience, 283, 2008-2010.

Burollet, P.F. \& Rouvier, H. (1971). La Tunisie: Tectonique de l'Afrique (Sciences de la Terre, 6). Unesco publication, Paris, 91-100.

Burollet, P.F. (1973). Importance des fractures salifères dans la tectonique tunisienne. Annales des Mines et de la Géologie, Tunis, 111-120.

Caby, R., Hammor, D. \& Delor, C. (2001). Metamorphic evolution, partial melting and Miocene exhumation of lower crust in the Edough metamorphic core complex, west Mediterranean orogen, eastern Algeria. Tectonophysics, 342, 239-273. doi:10.1016/S0040-1951(01)00166-4, http://dx.doi.org/10.1016/S0040-1951(01)00166-4

Caglari, I. \& Duvarci, E. (2001). Geoelectric structure of inland area of the Gokova rift, southwest Antalia and its tectonic implications. Journal of Geodynamics, 31, 33-48. doi:10.1016/S0264-3707(00)00014-4,

http://dx.doi.org/10.1016/S0264-3707(00)00014-4

Diener, J.F.A., Stevens, G. Kisters, A. F.M., \& Poujol, M. (2005). Metamorphism and exhumation of the basal parts of the Barberton greenstone belt, South Africa: Constraining the rates of Mesoarchaean tectonism. Precambrian Research, 143, 87-112. doi:10.1016/j.precamres.2005.10.001, http://dx.doi.org/10.1016/j.precamres.2005.10.001

Dobrin, M.B. (1976). Introduction to Geophysical Prospecting. New York: Mc Graw-Hill.

Domzig, A., Le Roy, C., Déverchère, J., Yelles, K., Bouillin, J.-P., Bracène, R., Mercier de Lépinay, B., Le Roy, P., Calais, E., Kherroubi, A., Gaullier, V., Savoye, B., \& Pauc, H. (2006). Searching for the Africa-Eurasia Miocene boundary offshore western Algeria (MARADJA'03 cruise). C. R. Geoscience, 338, 80-91. doi:10.1016/j.crte.2005.11.009, http://dx.doi.org/10.1016/j.crte.2005.11.009

Durand Delga, M. (1955). Etude géologique de l'Ouest de la chaîne numidique. PhD thesis, University Paris IV. 
Epov, M.I., Nevedrova, N.N. \& Sanchaa, A.M. (2007). A geoelectrical model of the Barguzin basin in the Baikal Rift Zone, Russian. Geology and Geophysics, 48, 626-641. doi:10.1016/j.rgg.2007.06.001, http://dx.doi.org/10.1016/j.rgg.2007.06.001

Glaçon, G. \& Rouvier, H. (1972). Age des mouvements tectoniques majeurs en Tunisie septentrionale. $C$. $R$. Géosciences, 274, 1257-1260.

Gottis, Ch. \& Sainfeld P. (1955). Note explicative de la carte géologique de la Tunisie au 1/50. 000 ème. Feuille n 31: Ghardimaou. Report of geological office, Tunisia.

Gueddiche, M., Harjono, H, Ben Ayed, N., Hfaiedh, M., Diament, M. \& Dubois, J. (1992). Analyse de la sismicité et mise en évidence d'accidents actifs dans le Nord de la Tunisie. Bull. Soc. Géol. France, 4, 415-425.

Guellala, R., Inoubli, M. H. \& Amri, F. (2009). Nouveaux éléments sur la structure de l'aquifère superficiel de Ghardimaou (Tunisie): contribution de la géophysique électrique. Hydrological Sciences Journal, 5, 974-983. doi:10.1623/hysj.54.5.974, http://dx.doi.org/10.1623/hysj.54.5.974

Hfaiedh, M., Chadi, M., \& Allouche, M. (1985). Seismicity of Tunisia and neighbouring areas. Proceedings of the second workshop on the European Geotraverse Project: European Science Foundation, 261-267.

Jenny, J. \& Borreguerro, M. (1993). WINSEV, programme d'interprétation des sondages électriques verticaux réalisés selon le dispositif Schlumberger.

Keller, G.V. \& Frischknecht F.C. (1982). Electrical Methods in Geophysical Prospecting. Oxford: Pergamon Press.

Lepvrier C., and Mougenot J. (1984). Déformations cassantes et champs de contraintes post-hercyniennes dans l'Ouest de l'Ibérie. Rev. Geol. Dynam. Géogr. Phys., 25, 291-305.

Majumdar, R.K., Majumdar, N. \& Mukherjee, A.L. (2000). Geoelectric investigations in Bakreswar geothermal area, West Bengal, India. Journal of Applied Geophysics, 45, 187-202. doi:10.1016/S0926-9851(00)00028-8, http://dx.doi.org/10.1016/S0926-9851(00)00028-8

Manaa, M. (1986). Carte des Ressources en eau souterraine de la Tunisie à l'échelle du 1/200.000. Feuilles n 1 et 4. Tabarka et Souk el Arba, Ministry for Agriculture and the Water Resources, Tunisia.

Martinez, C. \& Truillet, R. (1987). Evolution structurale et paléogéographique de la Tunisie. Mém. Soc.Geol. It., 38, 35-45.

Morel, J.-L. \& Meghraoui, M. (1996). Gorringe-Alboran-Tell tectonic zone: A transpression system along the

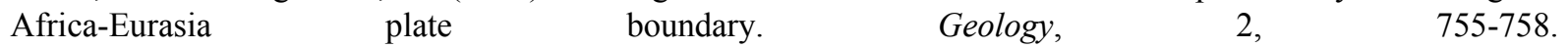
doi:10.1130/0091-7613(1996)024<0755:GATTZA>2.3.CO;2, http://dx.doi.org/10.1130/0091-7613(1996)024<0755:GATTZA>2.3.CO;2

Ould Bagga, M. (2003). Evolution tectono-sédimentaire et analyse structurale d'un segment des magrébides orientales: la région de Ghardimaou-Fernana (Tunisie Nord occidentale). $\mathrm{PhD}$ thesis, University Tunis II.

Perthuisot, V. (1978). Dynamique et pétrogenèse des extrusions triasiques en Tunisie Septentrionale. PhD thesis, University Pierre et Marie Curie, Paris.

Ricou, L.E. (1994). Tethys reconstructed: plates, continental fragments and their boundaries since 260 Ma from Central America to South-Eastern Asia. Geodyn. Acta., 7, 169-218.

Ring, U., Kröner, A., \& Toulkeridis, T. (1997). Palaeoproterozoic granulite-facies metamorphism and granitoid intrusions in the Ubendian-Usagaran Orogen of northern Malawi, east-central Africa. Precambrian Research, 85, 27-51. doi:10.1016/S0301-9268(97)00028-4, http://dx.doi.org/10.1016/S0301-9268(97)00028-4

Rouvier, H. (1973). Overthrusting in northern Tunisia: Proofs and paleogeographic consequences. Annales des Mines et de la Géologie, Tunis, 33-47.

Rouvier, H. (1977). Géologie de l'extrême -Nord tunisien : tectoniques et paléogéographies superposées à l'extrémité orientale de la chaîne nord -maghrébine. PhD thesis, University Paris VI.

Telford, W.M., Geldart, B.P. \& Sheriff, R.E. (1976). Applied Geophysics. Cambridge London: Univervity Press. Villa, J.M. (1980). La chaîne alpine d'Algérie orientale et des confins algéro-tunisiens. PhD thesis, University Paris VI.

Zouari, H. (1995). Evolution géodynamique de l'Atlas centro-méridional de la Tunisie. Stratigraphie, analyses géométriques, cinématiques et tectono-sédimentaires. $\mathrm{PhD}$ thesis, University Tunis II. 
Zouhri, L., Gorini, C., Mania, J., Deffontaines, B. \& Zerouali, A. (2004). Spatial distribution of resistivity in the hydrogeological systems, and identification of the catchment area in the Rharb basin, Morocco. Hydrological Science Journal, 49, 387-398. doi:10.1623/hysj.49.3.387.54350, http://dx.doi.org/10.1623/hysj.49.3.387.54350

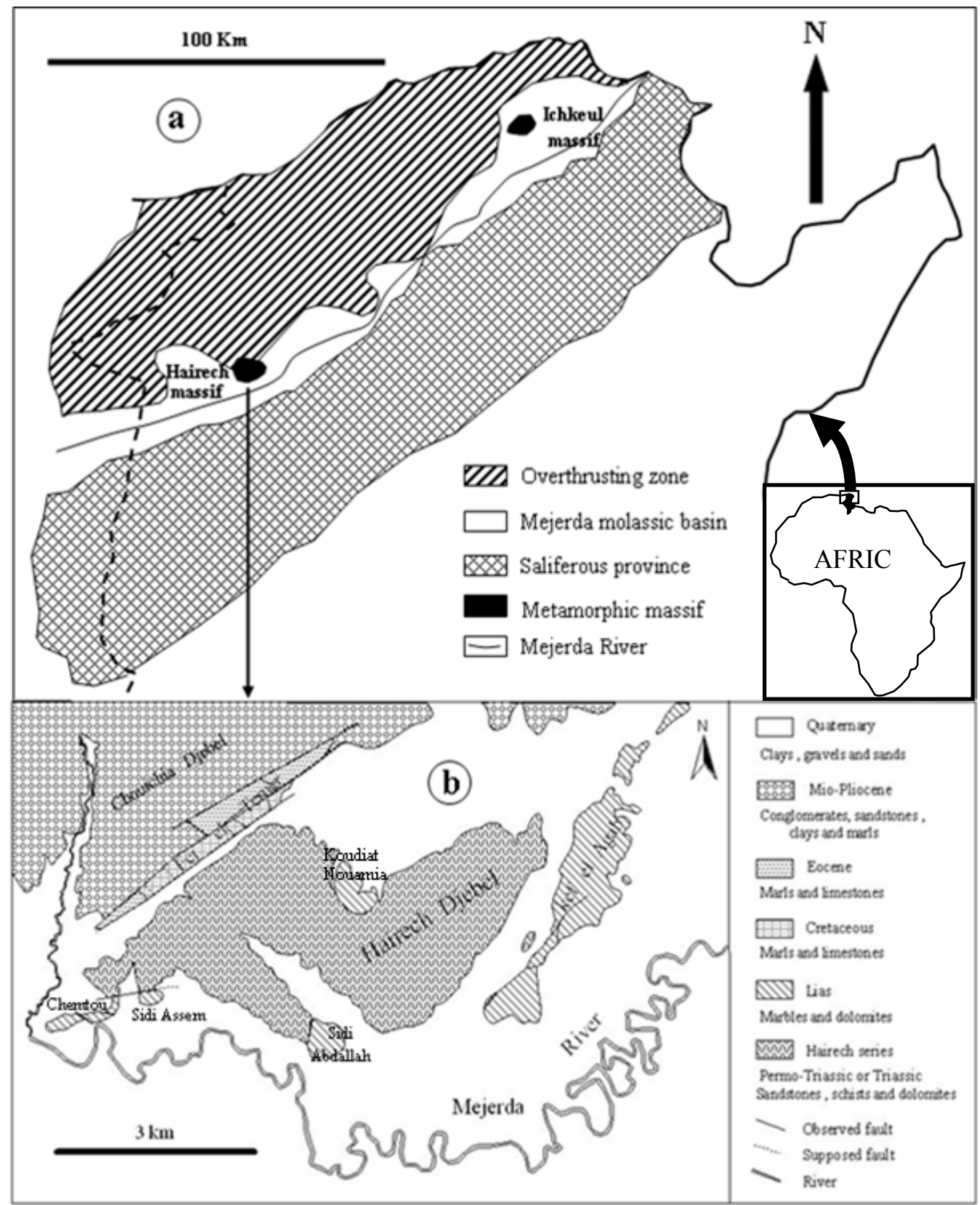

Figure 1. Structural setting and geology of the Hairech massif.

(a) Structural elements of northern Tunisia (modified from Rouvier, 1977),

(b) Geological map of the Hairech massif (modified from Gottis \& Sainfeld, 1955) 


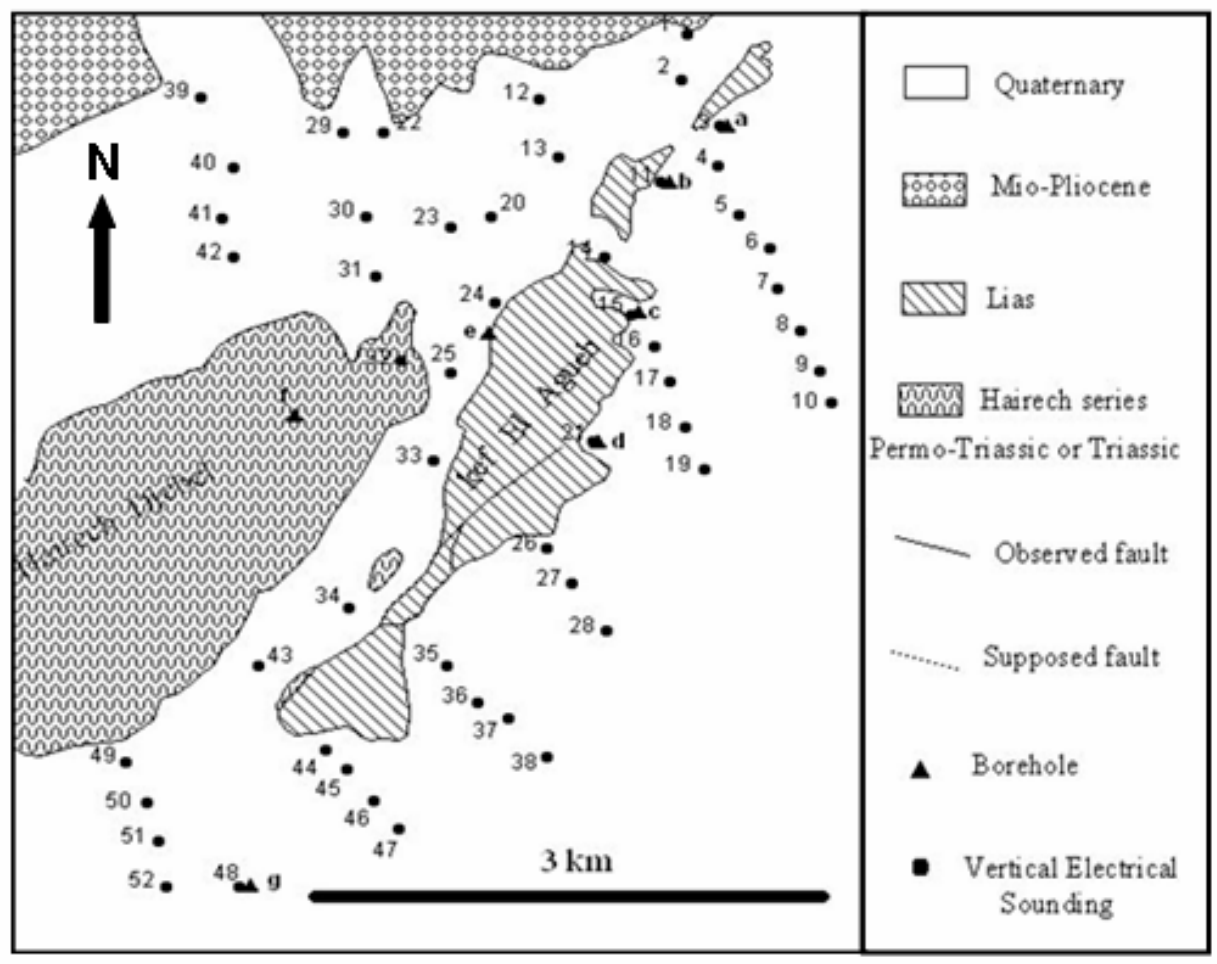

Figure 2. The vertical electrical soundings location

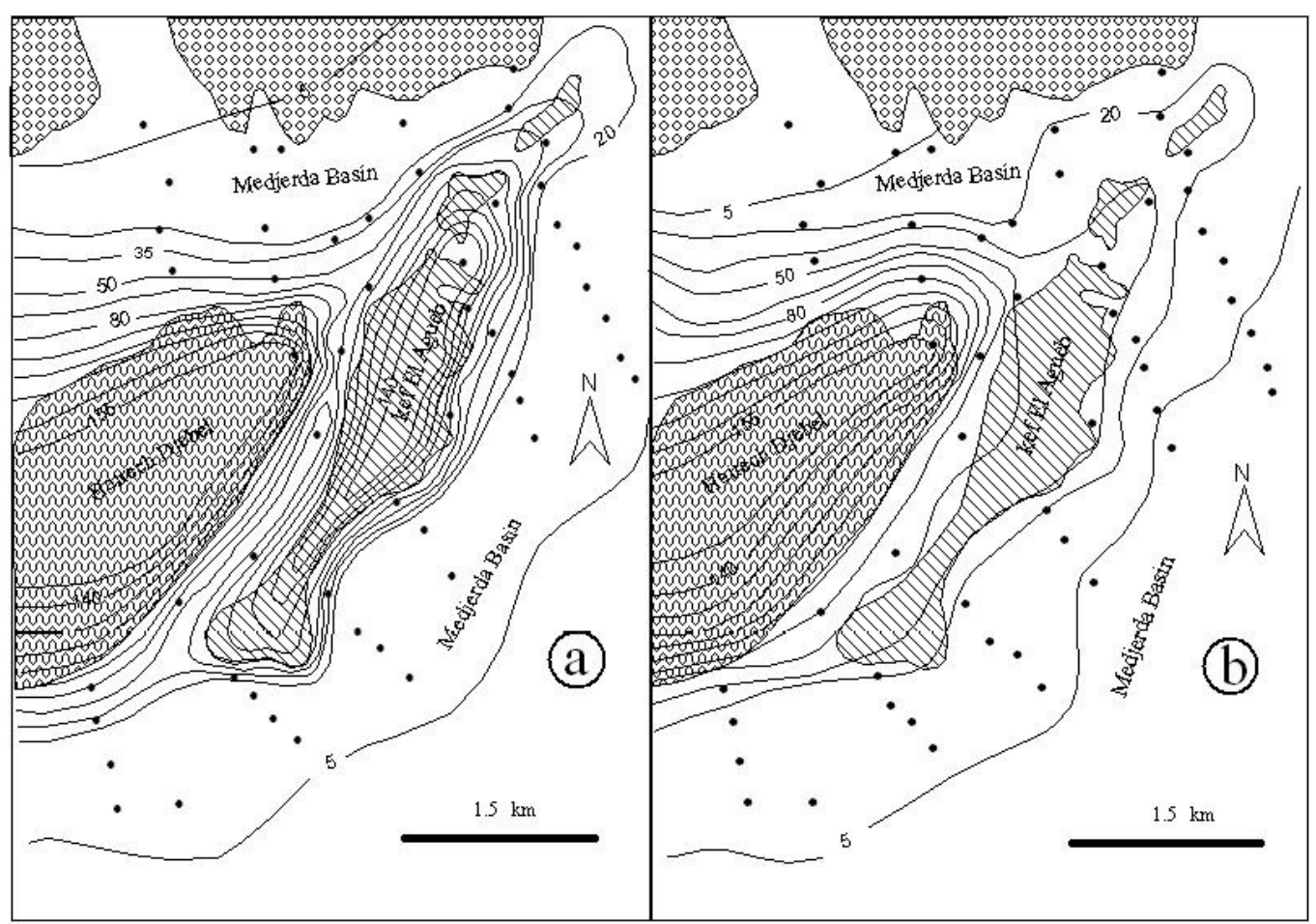

Figure 3. Apparent resistivity maps corresponding to 200 (a) and $1000 \mathrm{~m}$ (b) electrode spacings $(A B)$. Contour lines are in Ohm. m. Points show the vertical electrical sounding sites (see Fig. 2) 


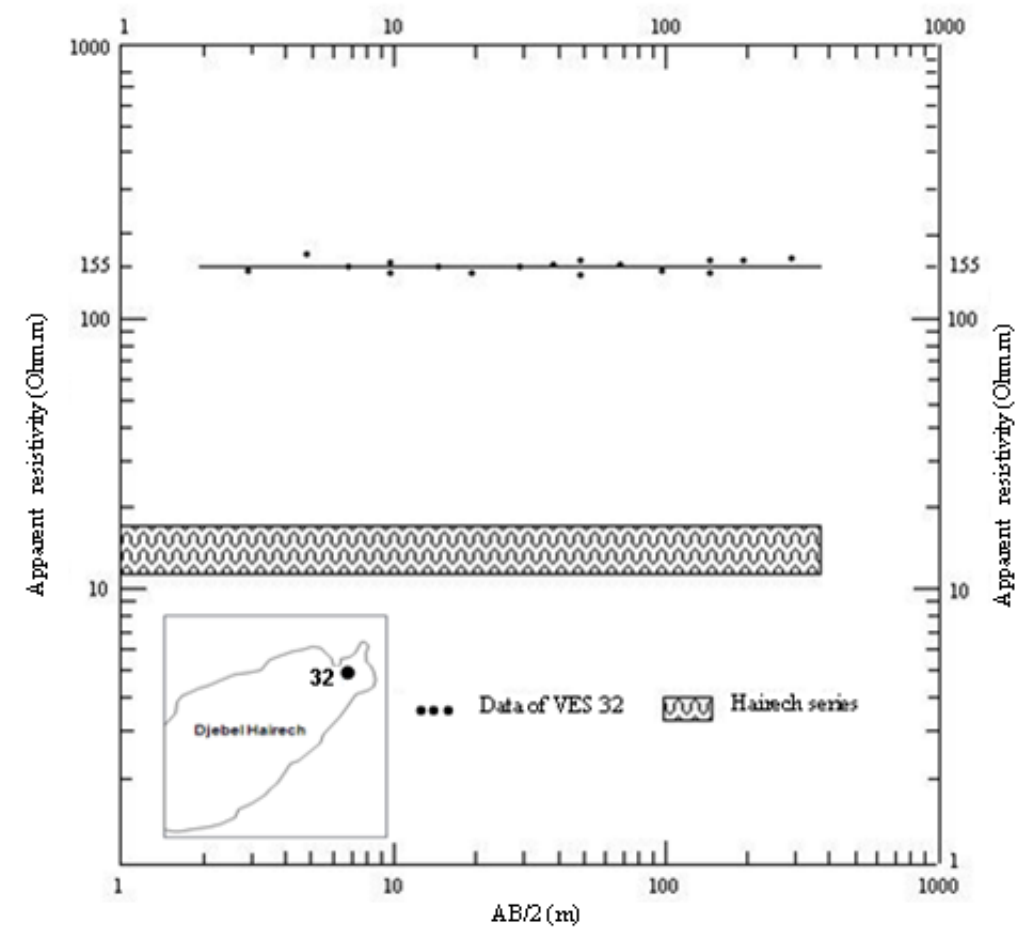

Figure 4. Electrical identification of the Hairech series

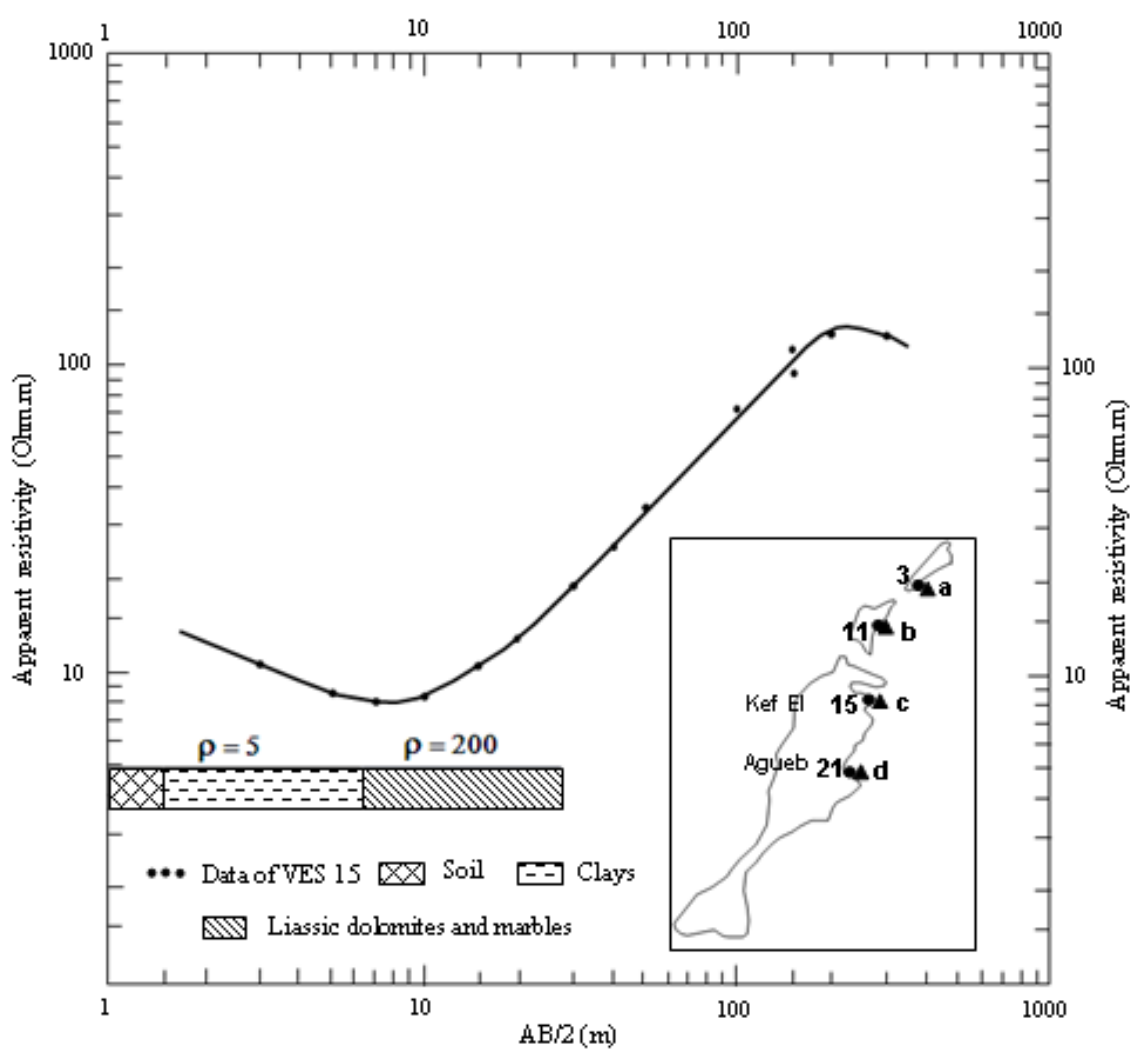

Figure 5. Electrical identification of Liassic dolomites and marbles (Example: VES 15 calibrated with the borehole c) 


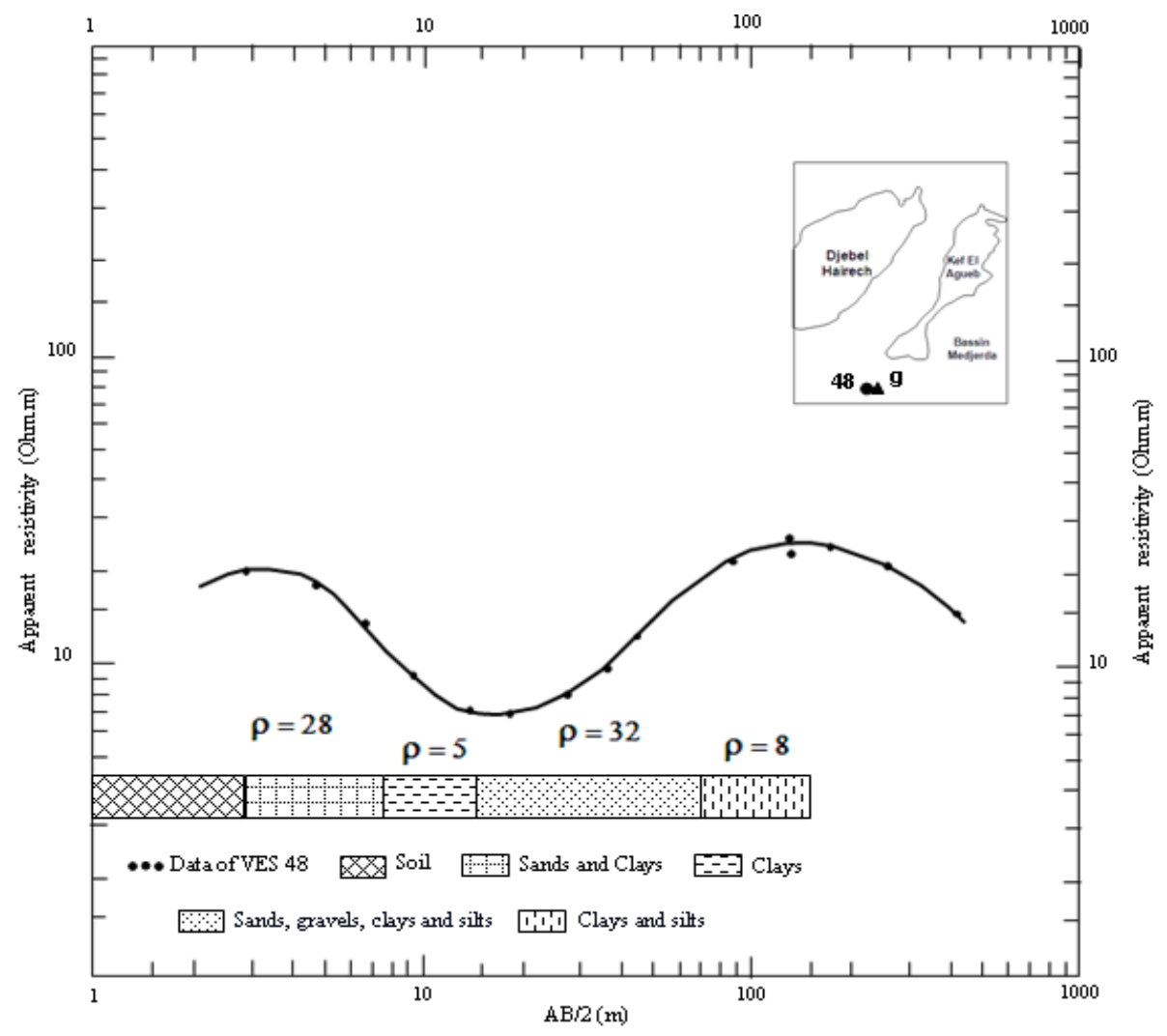

Figure 6. Electrical identification of the Mio-Plio-Quaternary series (VES 48 calibrated with the borehole $\mathbf{g}$ )

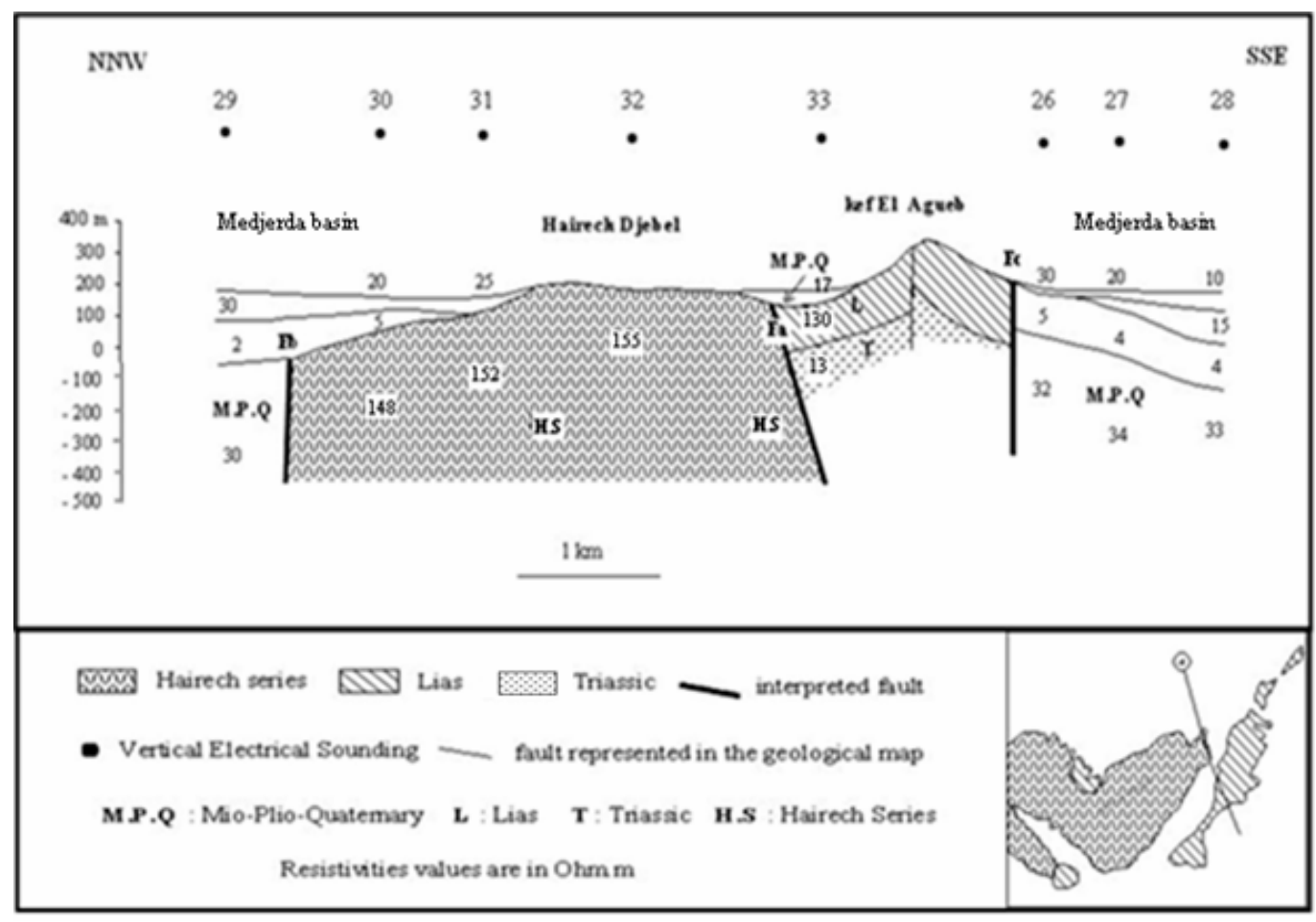

Figure 7. Geoelectric cross-section n 4 


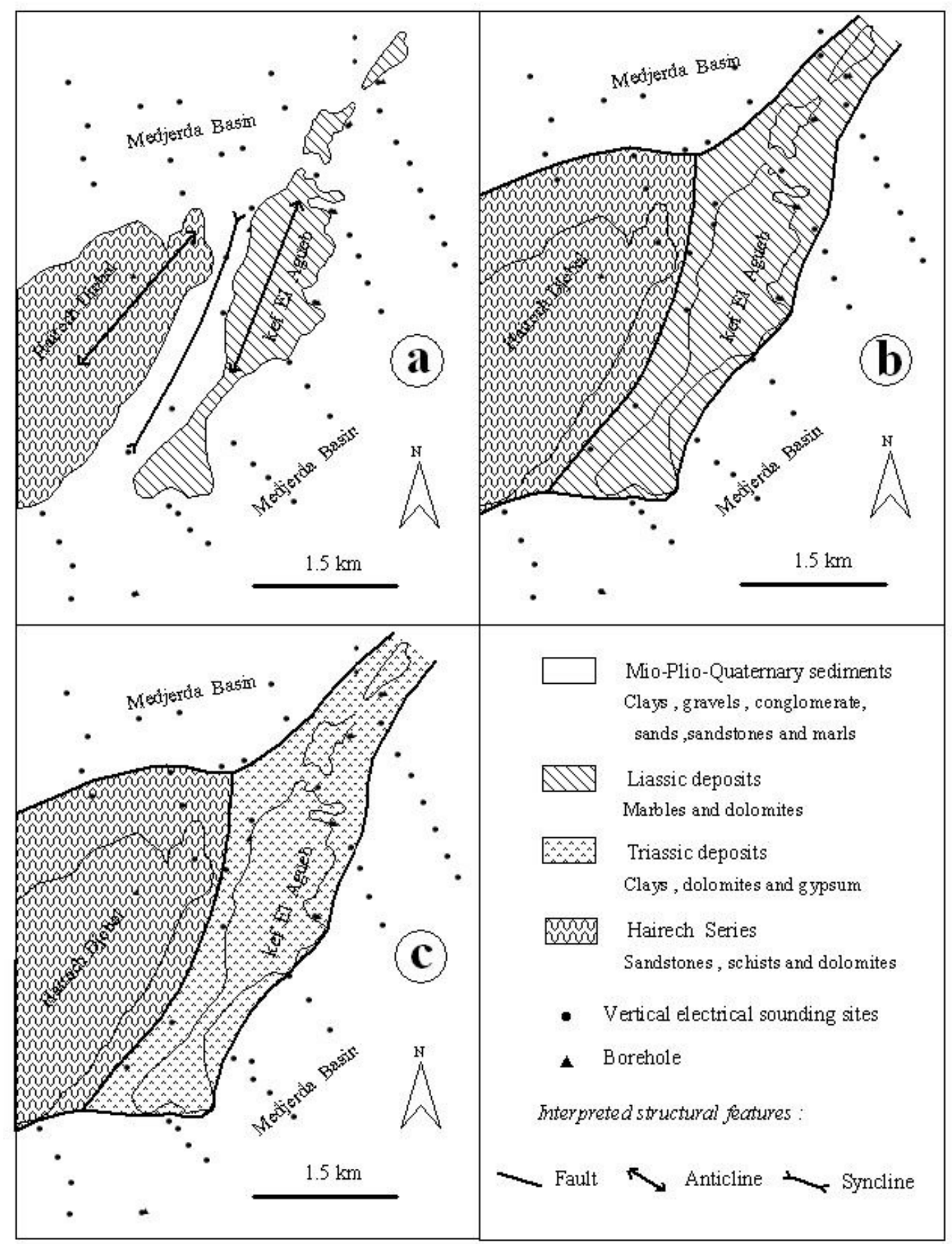

Figure 8. Subsurface geological maps.

a: Map drawn for $50 \mathrm{~m}$ depth level.

b: Map drawn for $150 \mathrm{~m}$ depth level.

c: Map drawn for $250 \mathrm{~m}$ depth level 